\title{
Порівняння перших результатів дослідження ефективності різних скорочених стандартних або модифікованих режимів лікування хворих на лікарсько-стійкий туберкульоз
}

Фещенко Ю.І. ${ }^{1}$, Литвиненко Н.А. ${ }^{2}$, Погребна М.В. ${ }^{2}$, Сенько А.С. ${ }^{1}$, Процик Л.М. ${ }^{2}$, Лафета А.С. ${ }^{1}$, Гранкіна Н.В.

1. ДУ «Національний інститут фтизіатрії і пульмонології ім. Ф.Г. Яновського НАМН України», м. Київ, Україна

2. К3 «Дніпропетровське обласне клінічне лікувально-профілактичне об’єднання «Фтизіатрія» Дніпропетровської обласної ради», м. Дніпро, Україна

Обґрунтування. Туберкульоз із мульти- та широкою лікарською стійкістю (МЛС-ТБ та ШЛС-ТБ) залишається однією 3 найактуальніших проблем охорони здоров'я. Ефективність лікування цієї категорії хворих, попри велику кількість різних груп антимікобактеріальних препаратів (АМБП), є низькою: ефективного лікування досягають лише в 50 \% випадків, у тому числі в Україні. Одні з причин втрати ефективності - тривалі курси антимікобактеріальної терапії (АМБТ) та завчасне припинення лікування (результат «втрачений для подальшого спостереження», що може бути встановлений у 20 \% хворих). Окрім того, дедалі більше накопичується даних у світі щодо швидкого темпу розвинення резистентності мікобактерій туберкульозу (МБТ) до нових АМБП - бедаквіліну та деламаніду. Саме тому вкрай актуальним $\epsilon$ проведення наукових досліджень щодо розроблення скороченого режиму хіміотерапії, котрий дасть змогу за оптимальні (скорочені) терміни досягти достатнього рівня ефективності з максимальним рівнем прихильності хворих до лікування та мінімальним ризиком розвитку резистентності МБТ до нових АМБП.

Матеріали та методи. Проведено проспективне обсерваційне дослідження щодо вивчення різних за складом скорочених режимів АМБТ у 346 хворих на МЛС-ТБ, які розпочали лікування протягом 2017-2020 рр. на базі ДУ «Національний інститут фтизіатрії і пульмонології ім. Ф.Г. Яновського НАМН України» та КЗ «Дніпропетровське обласне клінічне лікувально-профілактичне об'єднання «Фтизіатрія» Дніпропетровської обласної ради». Короткі режими лікування (КРЛ) були такі: 1-ша група (72 хворих) - КРЛ, рекомендований Всесвітньою організацією охорони здоров'я (В003): 4ZEAmMfxCfzPtHhd 5ZEMfxCfz; 2-га група (123 хворих) - 1-й модифікований КРЛ (мКРЛ-1): 6ZMfxLzdCmCs 6ZMfxLzdCs; 3-тя група (81 хворий) - мКРЛ-2: 6BdqLzdLfxCfzCs 3BdqLzdLfx; 4-та група (70 хворих) - мКРЛ-3: 6BdqLzdMfxhdCs 3BdqLzdMfxhd.

Результати. На момент завершення дослідження «успішного лікування» досягли всі хворі, в яких застосовували всі мКРЛ, порівняно із 72,5 \% пацієнтів на КРЛ за ВООЗ ( $><0,05)$. Щодо мКРЛ, то 9-місячні були однакові за ефективністю з 12-місячним, і за жодного з цих режимів не спостерігалося рецидивів. Але було визначено тенденцію: при 12-місячному режимі (мКРЛ-1) зареєстровано 5,8 \% перерв у лікуванні. Обидва 9-місячні модифіковані скорочені режими, що вивчалися, були однаково ефективними: припинення бактеріовиділення відбулося в усіх хворих у термін

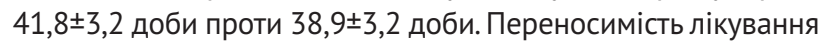
була значно кращою серед хворих, які отримували режим лікування з моксифлоксацином порівняно з левофлоксацином і клофазиміном ( $<<0,05)$ : загальна кількість побічних реакцій була зафіксована в 30,0 \% проти 64,2 \% хворих, кількість побічних реакцій 3-4 ступеня вираженості була однаковою.

Висновки. Скорочені режими, як стандартний, так і модифіковані, показали високу ефективність у хворих на МЛС-ТБ. Протягом перших 2 місяців лікування негативація культури відбувалася більш ніж у 80,0 \% хворих. Прийнятнішими для використання $\epsilon$ 9-місячні мКРЛ. Зважаючи на профіль безпечності, пріоритетним для використання $є$ модифікований скорочений режим із моксифлоксацином порівняно з левофлоксацином і клофазиміном.

Таблиця. Остаточні результати лікування хворих, у яких застосовували різні види КРЛ

\begin{tabular}{|c|c|c|c|c|c|c|c|c|}
\hline \multirow{2}{*}{ Попередній результат лікування } & \multicolumn{2}{|c|}{$\begin{array}{c}\text { Група } 1 \text { (КРЛ): } \\
\text { n=51 }\end{array}$} & \multicolumn{2}{|c|}{$\begin{array}{c}\text { Група } 2 \text { (мКРЛ-1): } \\
n=103\end{array}$} & \multicolumn{2}{|c|}{$\begin{array}{c}\text { Група } 3 \text { (мКРЛ-2): } \\
\text { n=63 }\end{array}$} & \multicolumn{2}{|c|}{$\begin{array}{c}\text { Група } 4 \text { (мКРЛ-3) } \\
\text { n=43 }\end{array}$} \\
\hline & абс. & $\%$ & aбc. & $\%$ & aбc. & $\%$ & абc. & $\%$ \\
\hline Вилікування & 11 & 21,6 & 76 & 73,8 & 33 & 52,4 & 42 & 97,7 \\
\hline Лікування завершене & 26 & 51,0 & 21 & 20,4 & 30 & 47,6 & 1 & 2,3 \\
\hline Успішне лікування & 37 & 72,5 & 97 & 94,2 & 63 & 100 & 43 & 100 \\
\hline Невдача лікування & 5 & 9,8 & 0 & 0 & 0 & 0 & 0 & 0 \\
\hline Вибув із-під нагляду & 7 & 13,7 & 6 & 5,8 & 0 & 0 & 0 & 0 \\
\hline Помер & 2 & 3,9 & 0 & 0 & 0 & 0 & 0 & 0 \\
\hline Продовжує лікування & 0 & 0 & 0 & 0 & 0 & 0 & 0 & 0 \\
\hline
\end{tabular}

